\title{
Asymbiotic Germination and Seedling Development of Terrestrial Orchid Bletilla striata Using in vitro and ex vitro Cultures
}

\section{Mehmet Uğur KAHRAMAN ${ }^{1}$, , Francis John CULLUM²}

\author{
${ }^{1}$ Batı Akdeniz Agricultural Research Institute, 07100, Antalya / Turkey \\ ${ }^{2}$ Writte University College Horticulture Department, Chelmsford / United Kingdom
}

\section{Article History}

Received 01 October 2020

Accepted 07 November 2020

First Online 15 December 2020

\section{Corresponding Author}

E-mail:

mugur.kahraman@tarimorman.gov.tr

\section{Keywords}

MS

Nutrient requirements

Sphagnum moss

Protocorm

\begin{abstract}
Procedures for asymbiotic germination and seedling development under in vitro and ex vitro conditions were investigated for Bletilla striata. Five different asymbiotic germination media ( $1 / 2$ P6668 $\neg$ Phytamax Orchid Maintenance Media, $1 / 2$ P6668 $\neg$ Phytamax Orchid Maintenance Media with coconut water, P723 PhytoTechnology Orchid Seed Sowing Media, P723 PhytoTechnology Orchid Seed Sowing Media with coconut water, and $1 / 2$ MS media) for in vitro culture and sphagnum moss for ex vitro culture were examined for their effectiveness for 8 weeks on seed germination and seedling development of B. striata. Germination occurred in all media, however, the best germination rate was obtained in P723 medium with coconut water while the lowest frequency was obtained in sphagnum moss. Moreover, the highest leaf parameters of the seedlings of $B$. striata developed in $1 / 2$ MS medium when the seedlings in sphagnum moss showed the lowest results. Furthermore, all germinated protocorms showed rhizoid formation in all media.
\end{abstract}

\section{Introduction}

The Orchidaceae is among the largest flowering plant families with about 28500 species and 700 to 800 genera (Govaerts et al., 2018). Members of this family are distributed worldwide and are largely cultivated as ornamentals (Harrap, 2009). Orchid species are found in almost every place in the world (Arditti, 1990).

The East Asian endemic terrestrial orchid genus Bletilla has nine species distributed widely from north Myanmar and Indochina through Korea, China and Japan. Bletilla cotoensis, B. foliosa, B. japonica, B. morrisonicola, B. ochracea, B. sinensis, $B$. striata, B. szetschuanica, and B. yunnanensis species belong to the Bletilla genus (Dressler, 1993). This orchid is commonly known as Chinese ground orchid. The plant is an herbaceous perennial about $50 \mathrm{~cm}$ in height, with four to eight grass-like leaves, and a peduncle that forms in May to July. The plant has rose mauve coloured flowers in a racemous inflorescence (Tan, 1969).

Besides the ornamental characteristics, Bletilla striata has many compounds (bibenzyl, phenanthrene, dihydrophenanthrene and diphenanthrene) which have some biological effects, like antioxidant, antimicrobial etc. In China, people consume the tubers of this plant and were consuming with honey (Dong et al., 2014). Especially in China, B. striata is used in modern medicine also, not only traditional medicine. After tubers are collected from the plant, they are peeled and dried. People use that plant for bleeding, muscular damage, burns, skin wounds, ulcers and, liver tumours (Xiang et al., 2013; Wang et al., 2013; Peng et al., 2014; Zhang et al., 2019).

Orchid plants produce capsules, which are generally dry and mature, and each capsule has thousands of seeds and sometimes millions. The seeds of most flowering plants, have an endosperm, 
which is the food reserve, while most of the orchid seeds do not have endosperm, or have an undeveloped endosperm. Thus, orchid seeds are different from other Angiosperms. (Arditti and Ghani 2000; Seaton et al., 2011). However, some orchid species have endosperm inside of the seed, like Bletilla or Sobralia orchids (Arditti, 1992; Tullock, 2005; Zhi-Hui et al., 2006). Some people call orchid seeds "naked seeds" or "dust seeds" because of the lack of endosperm, hence, the seeds need a mycorrhizal fungus association to develop (Rasmussen, 1995; McKendrick, 2000; Seaton et al., 2011). With germination, the embryo of the orchid seed becomes bigger to form a protocorm. Afterwards, rhizoids develop, first leaves and roots appear respectively (Arditti, 1992). Furthermore, the development of $B$. striata has four stages: embryo, protocorm, rhizome, and pseudobulb (Zhang et al., 2019).

Orchid seeds can be germinated under in vitro conditions with the help of orchid mycorrhizal fungi called symbiotic germination. Seeds also can be germinated in media, which are not inoculated with fungi called asymbiotic germination. In the symbiotic media, the fungus provides water, minerals and energy source to the orchid seeds. However, in the asymbiotic media, all nutrient requirements are provided in complex formulations. Furthermore, asymbiotic medium is efficient for seed growing, not used only at the germination stage, but also for seedling growth (Seaton et al., 2011). The asymbiotic orchid seed germination method is really important for breeding and conservation of rare and native species. Moreover, it is important for species, which are difficult to germinate. With the asymbiotic germination method, large numbers of plants can be produced at the same time quickly and efficiently (Stenberg and Kane, 1998).

In the 1800's, the asymbiotic germination method was found difficult by the people, however, Lewis Knudson improved the solution of Wilhelm Pfeffer and created the Knudson B solution in 1921. After a while, Lewis Knudson created the Knudson C germination medium in 1946. He made it possible to germinate orchids without using fungi. Moreover, people started to think that orchid seeds could be germinated with simple nutrient media, which contain sugar (Arditti and Ernst, 1984; Arditti, 1990; Arditti, 2008). After Lewis Knudson, many researchers created and improved a lot of asymbiotic orchid media such as MS (Murashige and Skoog), Fast, VW (Vacin \& Went), MM (Malmgren Modified), RM (Reinert and Mohr), Curtis and Norstog. Moreover, there are some commercial media types like P6668 (Sigma Aldrich), P668, P723, B141, F522, T839, O156 (Phytotechnology Laboratory). The asymbiotic orchid medium contain macro and microelements, amino acids, polyol, vitamins, hydrolysates and autolysates, sugars, and gelling agents. Moreover, some formulations add some additional compounds to the asymbiotic orchid germination medium, like auxin, cytokinin, banana, pineapple juice, coconut water, anticontaminants, activated charcoal, etc. (Arditti and Ernst, 1993; Seaton and Ramsay, 2005; Arditti, 2008; Butcher and Marlow, 2008; Thomas, 2008; Seaton et al., 2011).

Terrestrial orchids are quite different than epiphytic orchids in terms of asymbiotic seed germination protocol (De Pauw et al., 1995). There are numerous previous studies about asymbiotic germination using different media formulations on several terrestrial orchids genera such as Cypripedium (Chu and Mudge, 1996; De Pauw et al., 1996; Szendrak, 1997; Yan et al., 2006; Bae and Choi, 2008; Klavina et al., 2009; Zhang et al., 2013; Huh et al., 2016; Huh et al., 2019), Dactylorhiza (Laurent et al., 2014; Gümüş et al., 2017), Serapias (Gümüş and Ellialtioglu, 2012; Bektas and Sokmen, 2016; Calevo et al., 2017; Acemi and Ozen, 2019), Cephalanthera (Szendrak, 1997; Hemrova et al., 2019), Paphiopedilum (Lee, 2007; Zeng et al., 2012), Chloraea (Pereira et al., 2017; Quiroz et al., 2017), Bletia (Dutra et al., 2008), Geodorum (Bhadra and Hossain, 2003), Habenaria (Stewart and Kane, 2006), Peristylus (Thakur and Dongarwar, 2017), Anacamptis (Magrini et al., 2019), Bipinnula (Pereira et al., 2015), Pecteilis (Kim et al., 2019), Epipactis (Hemrova et al., 2019), Himantoglossum (Szendrak, 1997; Dulic et al., 2019), Spathoglottis (Barrientos and Fang, 2019), Anoectochilus and Haemaria (Chou and Chang, 2004), Calopogon and Socoila (Kauth, 2005), Gastrodia (Godo et al., 2020), Calanthe (Bae and Kim, 2015), Spiranthes (Dulic et al., 2019), Ophrys, Barlia, and Platanthera (Szendrak, 1997; Calevo et al., 2017). Furthermore, optimization for asymbiotic seed germination protocol of Bletilla striata has been described by Szendrak (1997), Fu et al. (2006), Ye et al. (2010), Su-qin, (2010), Godo et al. (2011), Kulpa and Katron (2012), , Yili et al. (2012), Billard et al. (2013), Zhang et al. (2013), Song et al. (2014), Nie et al. (2016), Min et al. (2017), and Wei et al. (2018).

The objective of this experiment was to select the best germination and seedling development media for Bletilla striata.

\section{Material and Method}

\subsection{Acquisition of orchid seeds}

Bletilla striata seeds were donated by Thompson \& Morgan Company. They were collected when they were ripe. The seeds were checked under the microscope (Wild Heerburg, Switzerland) and only seeds, which had an embryo were used. Besides, the $B$. striata seeds were extremely small (Figure 1).

\subsection{Asymbiotic media screen}




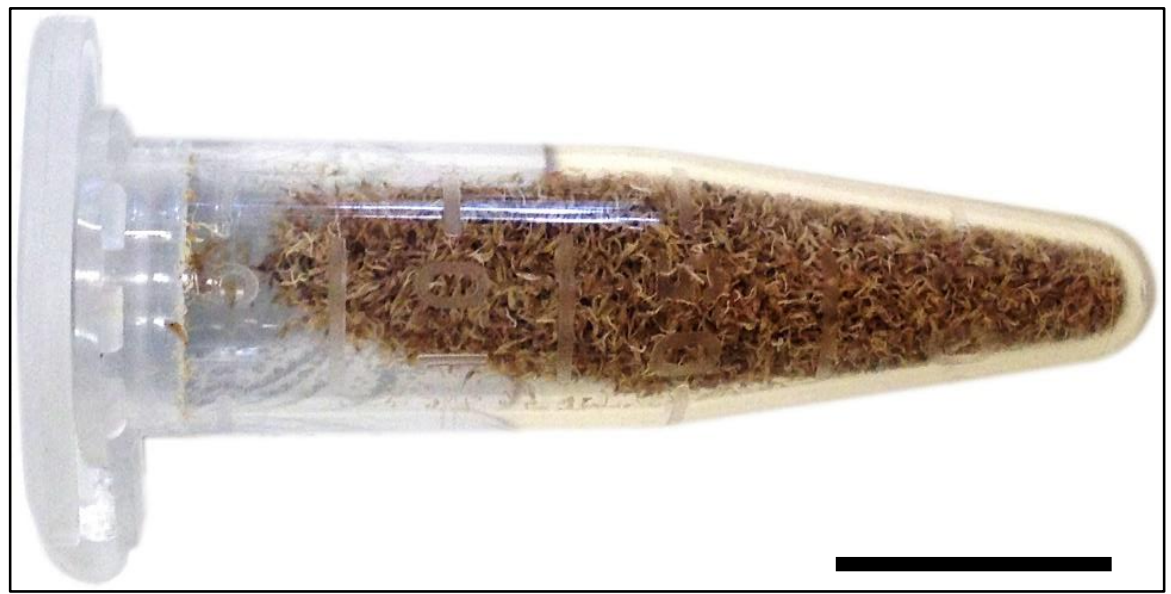

Figure 1. The seeds of Bletilla striata (Scale bar $=10 \mathrm{~mm}$ )

Table 1. Nutrient composition of germination media used for the asymbiotic seed germination of Bletilla striata

\begin{tabular}{|c|c|c|c|c|}
\hline Nutrient elements & Formulations $\left(\mathrm{mg} \mathrm{L}^{-1}\right)$ & $1 / 2 \mathrm{MS}$ & $1 / 2 \mathrm{P} 6668$ & P723 \\
\hline \multirow{5}{*}{ Macro elements } & Ammonium Nitrate & 825 & 412.5 & 412.5 \\
\hline & Calcium Chloride Anhydrous & 166 & 83 & 83 \\
\hline & Magnesium Sulphate Anhydrous & 90.35 & 45.175 & 75.18 \\
\hline & Potassium Nitrate & 950 & 475 & 475 \\
\hline & Potassium Phosphate, Monobasic & 85 & 42.5 & 42.5 \\
\hline \multirow{9}{*}{ Micro elements } & Cobalt Chloride Hexahydrate & 0.0125 & 0.0063 & 0.0063 \\
\hline & Cupric Sulphate Pentahydrate & 0.0125 & 0.0063 & 0.0063 \\
\hline & Disodium EDTA Dihydrate & 18.65 & 18.65 & 18.65 \\
\hline & Ferrous Sulphate Heptahydrate & 13.9 & 13.9 & 13.9 \\
\hline & Boric Acid & 3.10 & 1.65 & 1.65 \\
\hline & Manganese Sulphate & 8.45 & 4.23 & 4.23 \\
\hline & Sodium Molybdate Dihydrate & 0.125 & 0.0625 & 0.0625 \\
\hline & Potassium lodide & 0.415 & 0.2075 & 0.2075 \\
\hline & Zinc Sulphate Heptahydrate & 4.30 & 2.65 & 2.65 \\
\hline \multirow{4}{*}{ Vitamins } & Myo-inositol & 50 & 50 & 100 \\
\hline & Nicotinic Acid (Free Acid) & 0.25 & 0.5 & 1 \\
\hline & Pyridoxine Hydrochloride & 0.25 & 0.5 & 1 \\
\hline & Thiamine Hydrochloride & 0.5 & 5 & 10 \\
\hline \multirow{5}{*}{ Organics } & Glycine & 1 & & \\
\hline & Peptone from Meat & & 1000 & 2000 \\
\hline & Activated Charcoal & & 1000 & 1000 \\
\hline & Sucrose & 20000 & 10000 & 20000 \\
\hline & MES (Free Acid) & & 500 & 500 \\
\hline
\end{tabular}

$1 / 2$ MS - Half-Strength Murashige and Skoog, P723 - PhytoTechnology Orchid Seed Sowing Media

$1 / 2$ P6668 - Half-Strength Phytamax Orchid Maintenance Media (Sigma Aldrich)

For this research the following media were chosen:

1. $1 / 2$ strength Phytamax P6668 orchid maintenance media (Sigma-Aldrich Co., UK).

2. $1 / 2$ strength Phytamax P6668 orchid maintenance media + coconut water.

3. P723 Orchid seed sowing media (PhytoTechnology Laboratories, USA).

4. P723 Orchid sowing media + coconut water.

5. $1 / 2$ strength Murashige and Skoog (MS) (Murashige and Skoog, 1962) (Sigma-Aldrich Co., UK).

6. Sphagnum Moss (Gardman Company, UK) (Table 1).

$1 / 2$ MS were modified with $2.0 \%$ sucrose (Sigma-

Aldrich Co., UK), and $0.8 \%$ agar (Oxoid-Termo Fisher Scientific, USA) were added to all media as a gelling agent. Moreover, $5.0 \%$ coconut water were added to $1 / 2$ P6668 and P723 media. The aim of decreasing strength to half is reducing the salt concentration to stimulate germination. Besides, coconut water has some nutrients and natural phytohormones, however, generally it is used as a supplement, not as a single medium. All media were adjusted to pH 5.8 (Seaton and Ramsey, 2005) and were taken to autoclave at $117.7 \mathrm{kPa}$ for $15 \mathrm{~min}$ at $121^{\circ} \mathrm{C}$.

\subsection{Surface sterilisation of the seeds}

For sterilizing seeds, the pocket method was used (Seaton and Ramsay, 2005; Gümüş, 2009), as the seeds were so tiny. Filter papers (Whatman grade no: $1,90 \mathrm{~mm}$ ) were folded and stapled to prevent seed loss (Figure 2). 100 seeds were added per pocket. 
Figure 2. Folding and stapling of filter paper for the pocket method

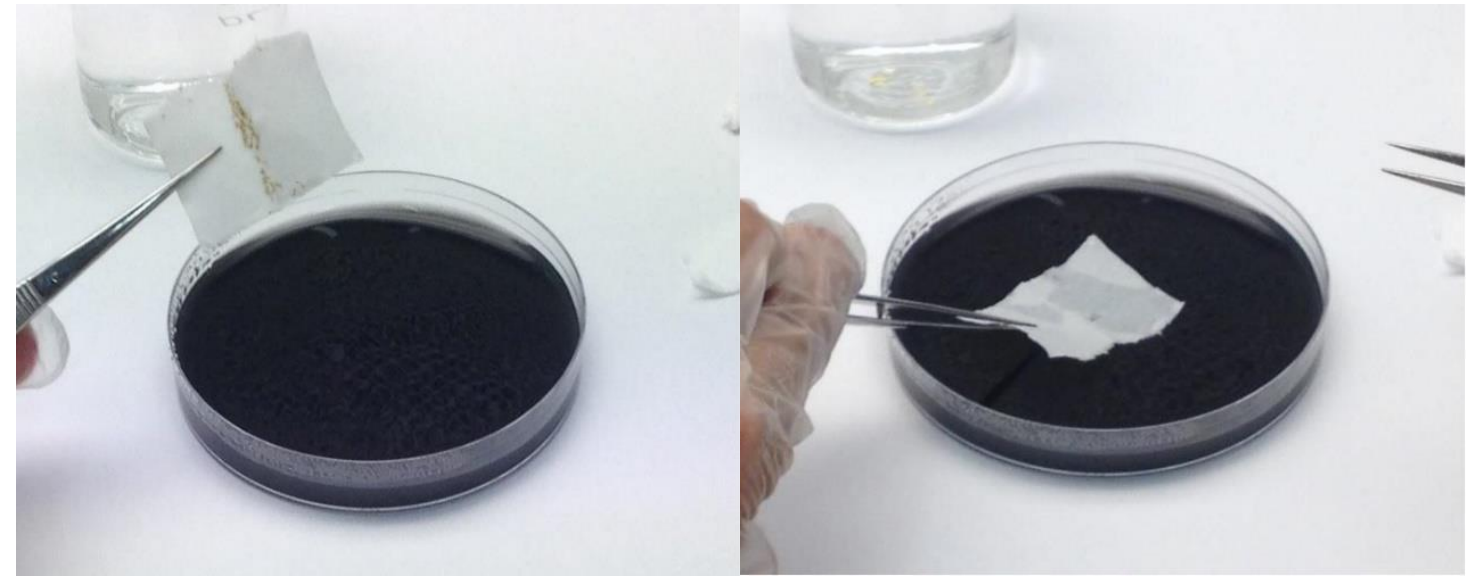

Figure 3. Sowing of the seeds

All the instruments, beakers, distilled water, filter papers, scissors, forceps, scalpels were covered with aluminium foil and sterilised in the autoclave for $20 \mathrm{~min}$ at $121^{\circ} \mathrm{C}$. The pockets were placed with the pair of forceps in the beaker, which had sterile distilled water, and were left there for $5 \mathrm{~min}$. After the water penetrated the filter papers, they were transferred to a beaker, which had bleach solution (10\% sodium hypochlorite) and was left there for 10 min and agitated gently. After sterilising process, filter papers were rinsed in the sterile distilled water and transferred to an empty beaker to allow excess liquid to drain.

\subsection{Sowing of the seeds}

While the pocket was held with forceps, staples were cut with scissors and opened gently. The filter paper was dabbed on the petri dish (Termo Fisher Scientific, USA) and then the seeds placed in the media (Figure 3).

\subsection{Incubation conditions}

Seeds were kept for germination at the temperature between $22-26^{\circ} \mathrm{C}$ (Zhi-Hui et al., 2006;
Kulpa and Katron, 2012) (recorded by TinyTag data logger). Dark treatment is not recommended by ZhiHui et al. (2006) and Kulpa and Katron (2012), therefore, petri dishes were kept between 2100 2600 lux (recorded by Lutron LX - 101 digital lux meter) for 14 hours in a day.

\subsection{Checking for germination and seedling development}

In the present study, 5 different parameters were observed: surface area of the leaves, length of the leaves, width of the leaves, number of leaves, and germination rate. 100 seeds were sown in each petri dish and 10 petri dishes were used for each media and parameter. For germination rate, all germinated seeds were counted. For the other parameters, 10 seeds were chosen randomly and were measured for each petri dish. The germination was determined when embryo ruptured the testa and became green. Germination rate was measured at 2nd, 3rd, 5th and 8th weeks, while the other parameters were measured at 3rd, 5th and 8th weeks. Leaf surface areas were measured according to Kindlmann and Balounova (1999) by formula of $q \times$ (length $x$ width). In this case $q$ was set as 0.5 . The microscopic 
photos were taken at $0.7 \mathrm{~m}$ (Invenio 3M Pixel CMOS Camera).

\subsection{Statistical analysis}

Obtained results were subjected to variance analysis employing a completely randomized design. Mean values for the examined plant traits were compared by Duncan multiple range test $\mathrm{a}=$ 0.05 by SAS software version 9.00 .

\section{Results and Discussion}

Germination rates of the seeds of $B$. striata were observed at $2^{\text {nd }}, 3^{\text {rd }}, 5^{\text {th }}$, and $8^{\text {th }}$ weeks. Over 8 weeks, the highest germination percentage was obtained in P723 media with coconut water with $71.31 \%$, while the lowest rate was investigated in sphagnum moss with $25.86 \%$. Moreover, $1 / 2$ P6668 media had the second-highest germination rate with $64.05 \%$ (Figure 4).

P723 Orchid Seed Sowing Media with coconut water showed the best germination results after 8 weeks. This situation can be explained by that coconut water can increase the germination success of orchids. Coconut water (or coconut milk) is preferred sometimes because it contains some nutrients and natural phytohormones. (Arditti and Ernst, 1993; Seaton and Ramsay, 2005; Arditti, 2008; Butcher and Marlow, 2008; Seaton et al., 2011). Using coconut water on the germination of $B$. striata has not been used in previous researches. The present study shows that using coconut water with P723 media can increase the germination percentage of $B$. striata. In previous researches, half-strength MS media has been preferred for germination of Bletilla seeds (Wei et al., 2018). Many researchers have studied the effect of the combination of plant growth regulators with $1 / 2 \mathrm{MS}$ media. According to the previous studies, the seeds can be germinated in higher rates with plant growth regulators. In the present study, $1 / 2 \mathrm{MS}$ without plant growth regulators showed the third-highest germination rate was obtained. The reason of this can be explained that other media have activated charcoal and lesser salt concentrations with a comparison of $1 / 2$ MS media. Activated charcoal is added to the orchid germination medium because this supplement adsorbs some compounds like phenols, vitamins and inorganic compounds and improves cell growth sometimes ( $P$ an and van Staden, 1998; Thomas, 2008). Activated charcoal affects adsorbing compounds, however, it is still not clear that activated charcoal helps to adsorb plant hormones or not. Some researchers think that it has an effect on plant hormones like the other compounds (macro, micro minerals, etc.). Orchid seeds are not dependent on activated charcoal; however, it has a positive effect on seed germination and development (Pierik et al., 1988).
Furthermore, activated charcoal has a positive effect on root development (Yan et al., 2006) and rhizome growth (Paek and Yeung, 1991). In the present study, germination rates reached to $71.31 \%$. Moreover, Ye et al. (2010) got $90 \%$ germination rate with $1 / 2 \mathrm{MS}+6$-benzyladenine (6BA) $1.0 \mathrm{mg} \mathrm{L}^{-1}+1 \%$ activated charcoal and Song et al. (2014) got almost $98 \%$ with the same medium components. Furthermore, Zhang et al. (2009) and Ding and Zheng (2016) got around $90 \%$ germination rate with $1 / 2 \mathrm{MS}+1.0 \mathrm{mg} \mathrm{L}^{-1}$ naphthalene acetic acid (NAA). Besides, Min et al. (2017) obtained 90\% germination rate with $1 / 2 \mathrm{MS}$ medium $+1.0 \mathrm{mg} \mathrm{L}^{-1} 6$ $\mathrm{BA}+0.1 \mathrm{mg} \mathrm{L}^{-1} \mathrm{NAA}$. Moreover, Kulpa and Katron (2012) reached $89 \%$ germination frequency by Knudson $C$ medium without any plant growth regulators. Unlike the other orchids, $B$. striata seeds store nutrients. Thus, there is a chance for direct sowing. In the present study, $25.86 \%$ germination frequency has been obtained by direct sowing of seeds on the sphagnum moss. Under the direct seed sowing conditions, spraying seeds with different nutrient solutions can increase the germination rate between $5 \%$ and $69.7 \%$ (Zhang et al., 2019). It is really important to demonstrate that $B$. striata seeds can germinate without auxin or cytokinin. There are a lot of factors that can affect seed germination success. For instance, the duration of the storage has a negative effect on the seeds of $B$. striata germination frequency. Hence, short-time storage is recommended (Zhang et al., 2019).

The percentage of rhizoid formation of the seedlings of $B$. striata were observed at $2^{\text {nd }}, 3^{\text {rd }}, 5^{\text {th }}$, and $8^{\text {th }}$ weeks. After week 5 , all the media showed the same rhizoid formation rate. Moreover, the seedlings in MS media and sphagnum moss showed slow rhizoid development in comparison with the other media at week 2 and 3 (Figure 5).

At the end of 8 weeks, all germinated protocorms formed rhizoid in all plant media. In the study by Godo et al. (2011), the effect of different wavelength of LED-lights on $B$. ochracea has been investigated. The highest rate of rhizoid formation was obtained by Orange LED-light with $71.7 \%$.

The lengths of the leaves of the seedlings of $B$. striata were investigated at $3^{\text {rd }}, 5^{\text {th }}$, and $8^{\text {th }}$ weeks. After 8 weeks, the highest length of the leaves was obtained in $1 / 2$ MS, $1 / 2$ P6668, $1 / 2$ P6668 media with coconut water, and P723 media with coconut water respectively in the same group. Moreover, it was observed that the length of the leaves in $1 / 2 \mathrm{MS}$ media climbed sharply after 8 weeks. Besides, the lowest length of the leaves was seen in sphagnum moss (Table 2).

The widths of the leaves of the seedlings of $B$. striata was investigated at $3^{\text {rd }}, 5^{\text {th }}$, and $8^{\text {th }}$ weeks. Over an 8-week period, the highest width of the leaves of the seedlings of $B$. striata was obtained in $1 / 2$ MS media. It was followed by $1 / 2$ P6668, $1 / 2$ P6668 media with coconut water, P723 media with coconut 


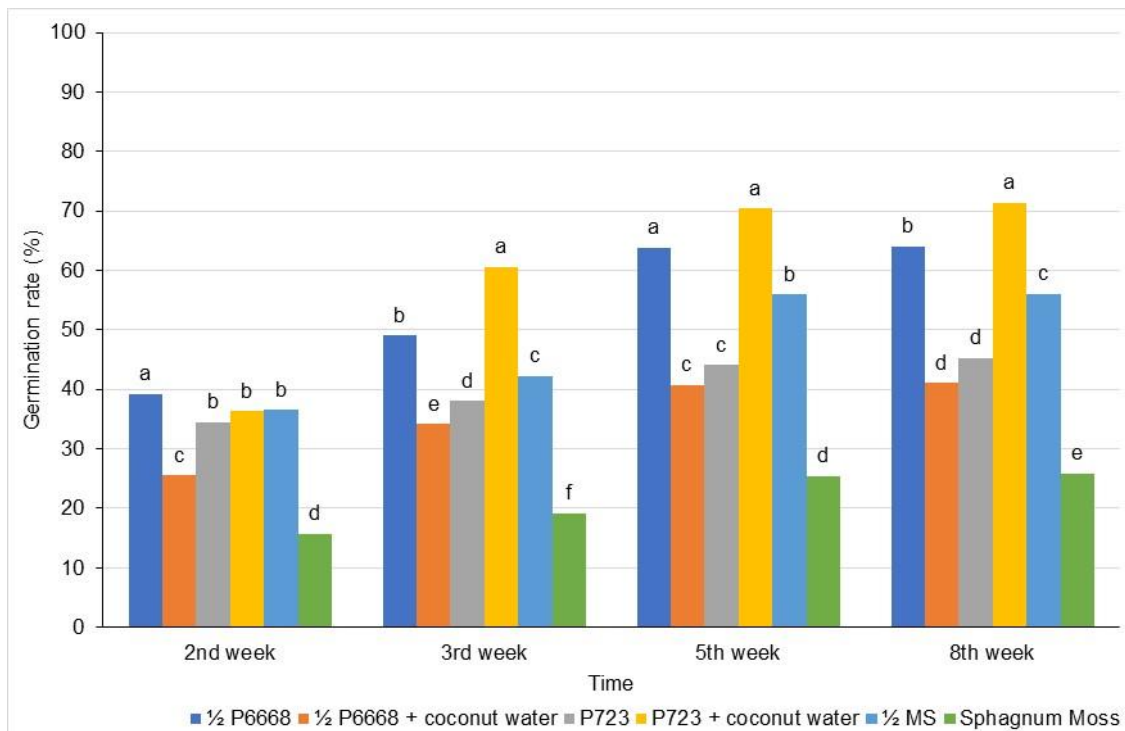

Figure 4. Comparative effects of culture media on germination rates of the seeds of Bletilla striata after 2, 3, 5, and 8 weeks (Bars with the same letters are not significantly different by Duncan's multiple range test at $\alpha=0.05$ ).

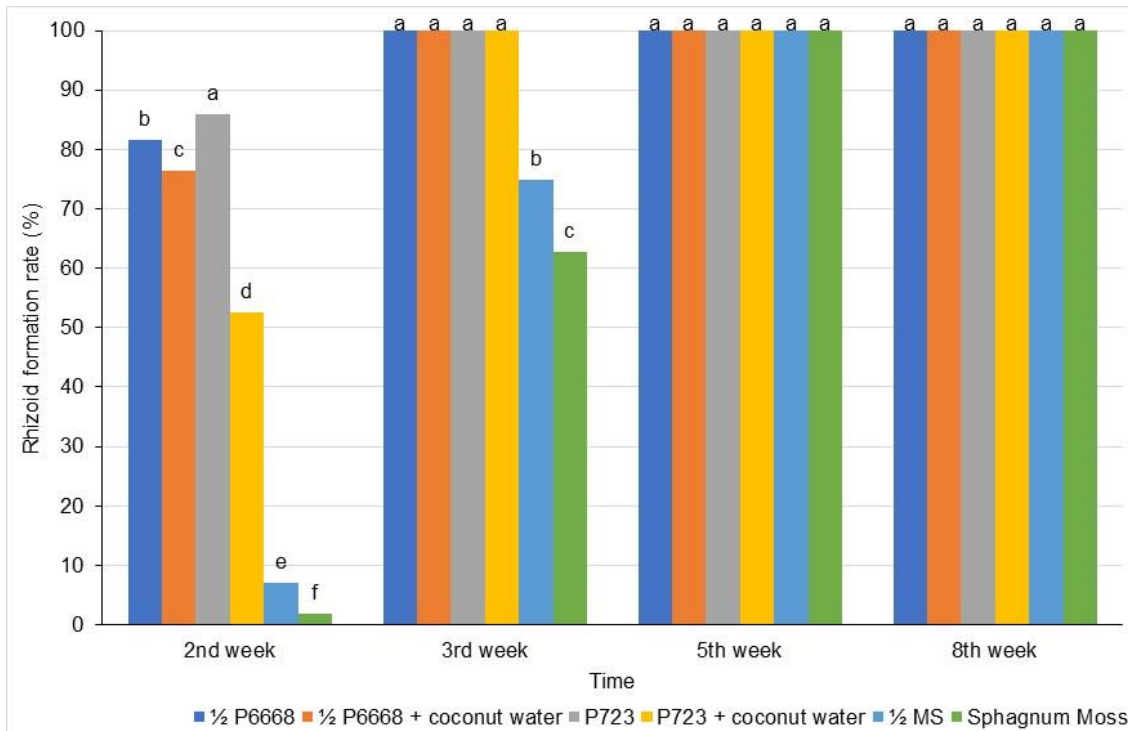

Figure 5. Comparative effects of culture media on the rhizoid formation rates of Bletilla striata after 8 weeks (Bars with the same letters are not significantly different by Duncan's multiple range test at $\alpha=0.05$.)

water respectively in the different group. Additionally, sphagnum moss had the lowest width of the leaves (Table 3).

The surface areas of the leaves of the seedlings of $B$. striata were investigated at $3^{\text {rd }}, 5^{\text {th }}$, and $8^{\text {th }}$ weeks. The highest width of the leaves of the seedlings of $B$. striata was obtained in $1 / 2 \mathrm{MS}$ media, $1 / 2$ P6668, P723 media with coconut water, and $1 / 2$ P6668 media with coconut water respectively in the same group. Like for the other seedling development parameters, the surface area of the leaves belongs to $B$. striata in MS media increased rapidly after $5^{\text {th }}$ week. Furthermore, the lowest surface area of the leaves was investigated in sphagnum moss (Table 4).

Results at the present study show that the highest leaf parameters of the seedlings of $B$. striata developed in $1 / 2$ MS medium at the end of the 8 weeks. Seedlings in $1 / 2$ P6668 media, P723 media with coconut water, and $1 / 2$ P6668 media with coconut water followed that respectively. Leaf parameters of seedlings in $1 / 2$ MS media climbed sharply between week 5 and week 8 . A possible reason is that $1 / 2$ MS media has a two times higher salts concentration than the other media. These results showed that the seedlings at $1 / 2$ P6668 medium, 1/2 P6668 medium with coconut water, P723 medium, and P723 medium with coconut water should have been transferred to the proliferation medium with higher salts for better seedling development. After germination, when the protocorms are formed, explants can be transferred to the proliferation media. Ye et al. (2010) indicated that the best proliferation media for $B$. striata is MS $+1.0 \mathrm{mg} \mathrm{L}^{-1} \mathrm{BA}+0.15 \mathrm{mg} \mathrm{L}^{-1} \mathrm{NAA}$. Moreover, Yili et al. (2012) stated that $\mathrm{MS}+1.0 \mathrm{mg} \mathrm{L}^{-1} \mathrm{BA}+$ $0.1 \mathrm{mg} \mathrm{L}^{-1}$ NAA performed the best shoot induction. Furthermore, Min et al. (2017) showed MS + 
Table 2. Comparative effects of culture media on length of the leaves of Bletilla striata after 3, 5, and 8 weeks

\begin{tabular}{lccc}
\hline \multirow{2}{*}{ Media } & \multicolumn{3}{c}{ Length of the leaves $(\mathrm{cm})$} \\
\cline { 2 - 4 } & $3^{\text {rd }}$ week & $5^{\text {th }}$ week & $8^{\text {th }}$ week \\
\hline $1 / 2$ P6668 & $0.83 \mathrm{a}$ & $2.13 \mathrm{a}$ & $2.84 \mathrm{a}$ \\
$1 / 2$ P6668 + coconut water & $0.67 \mathrm{~b}$ & $1.56 \mathrm{~b}$ & $2.75 \mathrm{a}$ \\
P723 & $0.59 \mathrm{~b}$ & $1.25 \mathrm{~b}$ & $2.05 \mathrm{~b}$ \\
P723 + coconut water & $0.58 \mathrm{~b}$ & $1.54 \mathrm{~b}$ & $2.57 \mathrm{ab}$ \\
$1 / 2$ MS & $0.41 \mathrm{c}$ & $0.93 \mathrm{c}$ & $2.95 \mathrm{a}$ \\
Sphagnum Moss & $0.35 \mathrm{c}$ & $0.65 \mathrm{c}$ & $0.93 \mathrm{c}$ \\
\hline
\end{tabular}

Measurements represent the mean of 100 seedlings per treatment. Measurements with the same letters are not significantly different by Duncan's multiple range test at $\alpha=0.05$.

Table 3. Comparative effects of culture media on the width of the leaves of Bletilla striata after 3, 5 , and 8 weeks

\begin{tabular}{lccc}
\hline \multirow{2}{*}{ Media } & \multicolumn{3}{c}{ Width of the leaves $(\mathrm{cm})$} \\
\cline { 2 - 4 } & $3^{\text {rd }}$ week & $0.60 \mathrm{a}$ & $8^{\text {th }}$ week \\
\hline $1 / 2$ P6668 & $0.26 \mathrm{a}$ & $1.21 \mathrm{~b}$ \\
$1 / 2$ P6668 + coconut water & $0.27 \mathrm{a}$ & $0.57 \mathrm{a}$ & $1.17 \mathrm{~b}$ \\
P723 & $0.26 \mathrm{a}$ & $0.46 \mathrm{ab}$ & $0.91 \mathrm{~b}$ \\
P723 + coconut water & $0.22 \mathrm{~b}$ & $0.54 \mathrm{a}$ & $1.12 \mathrm{~b}$ \\
$1 / 2$ MS & $0.20 \mathrm{ab}$ & $0.30 \mathrm{bc}$ & $1.60 \mathrm{a}$ \\
Sphagnum Moss & $0.15 \mathrm{~b}$ & $0.20 \mathrm{c}$ & $0.46 \mathrm{c}$ \\
\hline
\end{tabular}

Measurements represent the mean of 100 seedlings per treatment. Measurements with the same letters are not significantly different by Duncan's multiple range test at $\alpha=0.05$.

Table 4. Comparative effects of culture media on the surface area of the leaves of Bletilla striata after 3, 5 , and 8 weeks

\begin{tabular}{lccc}
\hline \multirow{2}{*}{ Media } & \multicolumn{3}{c}{ The surface area of the leaves $\left(\mathrm{cm}^{2}\right)$} \\
\cline { 2 - 4 } & $3^{\text {rd }}$ week & $5^{\text {th }}$ week & $8^{\text {th }}$ week \\
\hline $1 / 2$ P6668 & $0.11 \mathrm{a}$ & $0.66 \mathrm{a}$ & $2.15 \mathrm{ab}$ \\
$1 / 2$ P6668 + coconut water & $0.10 \mathrm{a}$ & $0.48 \mathrm{ab}$ & $2.07 \mathrm{ab}$ \\
P723 & $0.09 \mathrm{ab}$ & $0.33 \mathrm{bc}$ & $2.03 \mathrm{~b}$ \\
P723 + coconut water & $0.06 \mathrm{ac}$ & $0.43 \mathrm{ab}$ & $2.10 \mathrm{ab}$ \\
$1 / 2$ MS & $0.04 \mathrm{bc}$ & $0.16 \mathrm{~cd}$ & $2.35 \mathrm{a}$ \\
Sphagnum Moss & $0.03 \mathrm{c}$ & $0.06 \mathrm{~d}$ & $1.15 \mathrm{c}$ \\
\hline
\end{tabular}

Measurements represent the mean of 100 seedlings per treatment. Measurements with the same letters are not significantly different by Duncan's multiple range test at $\alpha=0.05$.

Table 5. Comparative effects of culture media on the number of the leaves of Bletilla striata after 3, 5, and 8 weeks

\begin{tabular}{lrrc}
\hline \multirow{2}{*}{ Media } & \multicolumn{3}{c}{ The number of the leaves } \\
\cline { 2 - 4 } & $3^{\text {rd }}$ week & $5^{\text {th }}$ week & $8^{\text {th }}$ week \\
\hline $1 / 2$ P6668 & $1.00 \mathrm{a}$ & $1.35 \mathrm{a}$ & $1.77 \mathrm{ab}$ \\
$1 / 2$ P6668 + coconut water & $1.00 \mathrm{a}$ & $1.22 \mathrm{a}$ & $1.75 \mathrm{ab}$ \\
P723 & $1.00 \mathrm{a}$ & $1.17 \mathrm{a}$ & $1.06 \mathrm{bc}$ \\
P723 + coconut water & $1.00 \mathrm{a}$ & $1.25 \mathrm{a}$ & $1.49 \mathrm{~b}$ \\
$1 / 2$ MS & $0.85 \mathrm{a}$ & $1.12 \mathrm{a}$ & $2.54 \mathrm{a}$ \\
Sphagnum Moss & $0.60 \mathrm{~b}$ & $1.00 \mathrm{a}$ & $0.21 \mathrm{c}$ \\
\hline
\end{tabular}

Measurements represent the mean of 100 seedlings per treatment. Measurements with the same letters are not significantly different by Duncan's multiple range test at $\alpha=0.05$.

$0.5 \mathrm{mg} \mathrm{L}^{-1} 6-\mathrm{BA}+0.2 \mathrm{mg} \mathrm{L}^{-1} \mathrm{NAA}+50.0 \mathrm{~g} \mathrm{~L}^{-1}$ mashed potato as the best proliferation media. Besides, some studies demonstrated that directly inducing cluster buds without proliferation process is possible (Ding and Zheng, 2016). Moreover, Fu et al. (2006) indicated that coconut water can induce proliferation as well. At the present study, it was observed that cluster buds and leaves can be formed without proliferation process and using media without plant growth regulators.

The numbers of the leaves of the seedlings of $B$. striata were investigated at $3^{\text {rd }}, 5^{\text {th }}$, and $8^{\text {th }}$ weeks. The highest number of the leaves of the seedlings of $B$. striata was obtained in $1 / 2 \mathrm{MS}, 1 / 2 \mathrm{P} 6668$, and $1 / 2$ P6668 media with coconut water after 8 weeks. Moreover, seedling grown in the sphagnum moss showed the lowest number of the leaves (Table 5). The number of leaves at the end of 8 weeks reached to 2.54 with $1 / 2$ MS media. Billard et al. (2013) found similar results as 2 to 3 leaves with $1 / 2$ MS after 7 weeks. In another study by Kulpa and Katron (2012), plant growth regulators in different amounts have been combined with Knudson $\mathrm{C}$ media. After 13 weeks, researchers obtained 3.0 leaves per seedling with Knudson C, Knudson C + $0.20 \mathrm{mg} \mathrm{L}^{-1} \mathrm{IBA}$, and Knudson $\mathrm{C}+0.50 \mathrm{mg} \mathrm{L}^{-1} \mathrm{IBA}$, 4.33 leaves with Knudson $C+0.50 \mathrm{mg} \mathrm{L}^{-1} \mathrm{BAP}$, and 5.66 leaves with Knudson $\mathrm{C}+0.20 \mathrm{mg} \mathrm{L}^{-1} \mathrm{NAA}$. As it is seen in the previous research, the number of leaves can be increased with auxin and cytokinin hormones.

The seeds of $B$. striata germinated, and seedlings developed in all media. Besides the measurements of the parameters, microscope images were observed at the $2^{\text {nd }}, 3^{\text {rd }}, 5^{\text {th }}$, and $8^{\text {th }}$ weeks (Figure 5, 6, 7, and 8). 


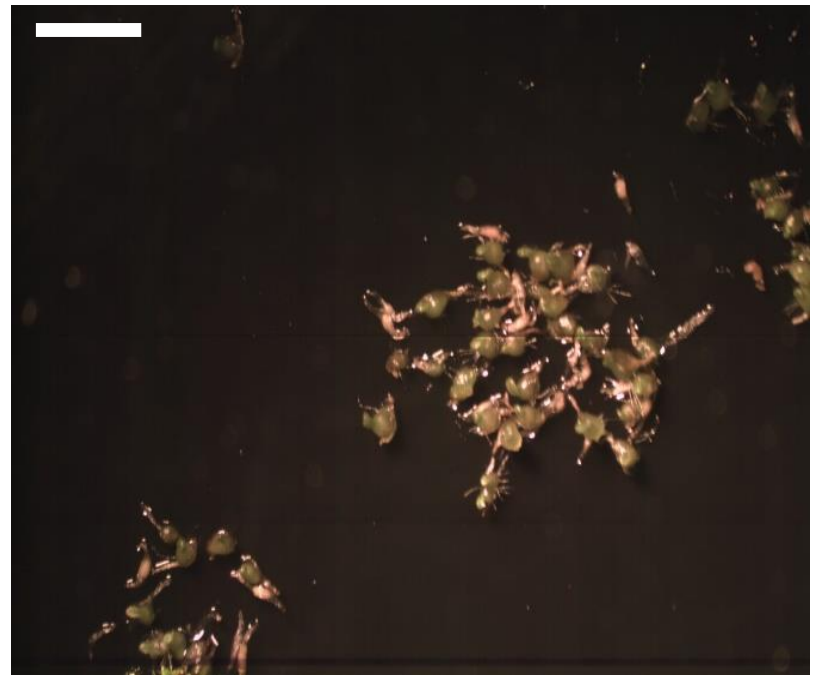

a

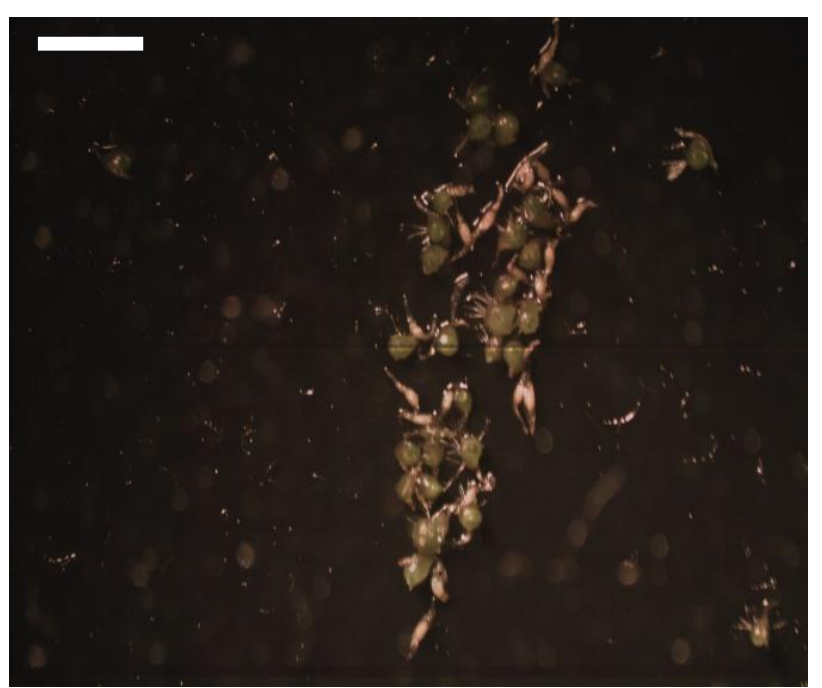

$c$

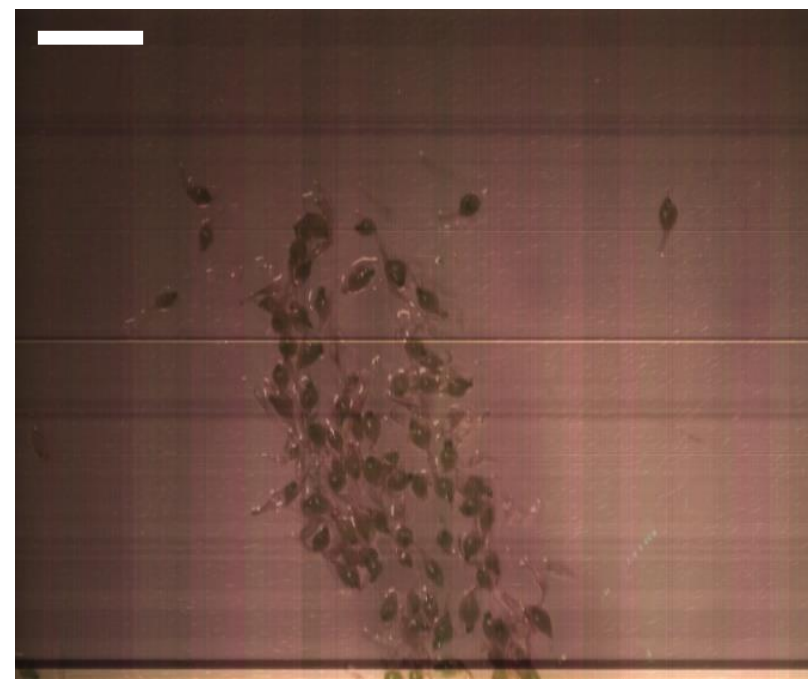

e

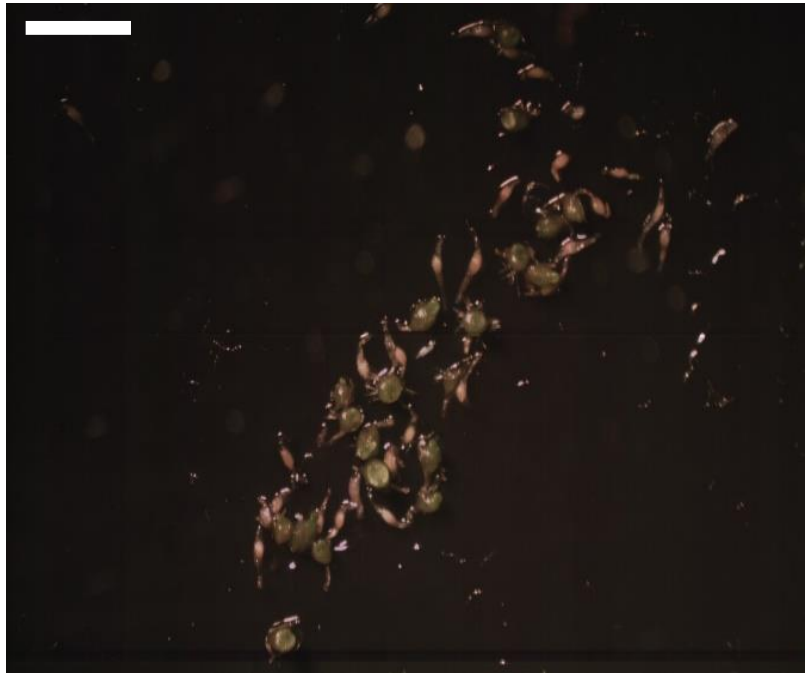

b

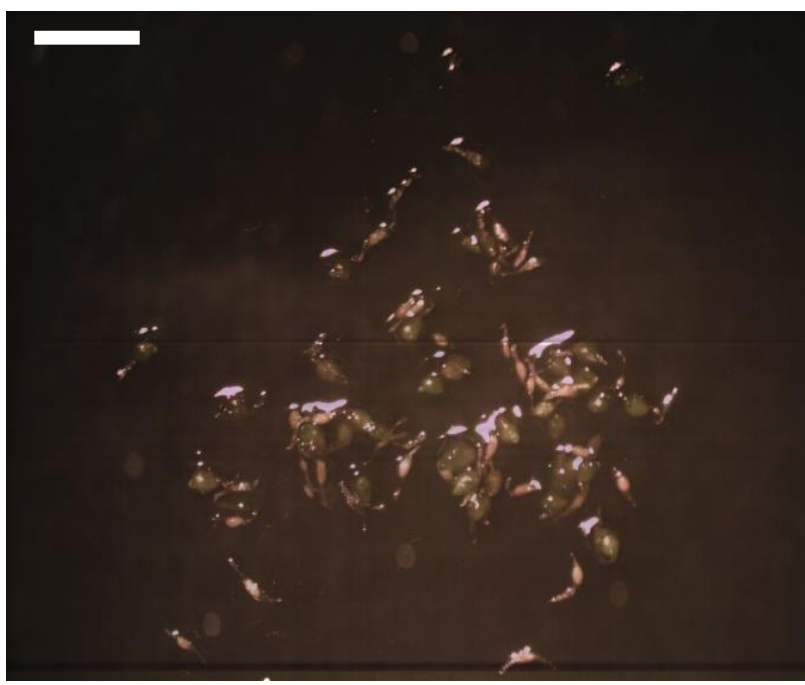

d

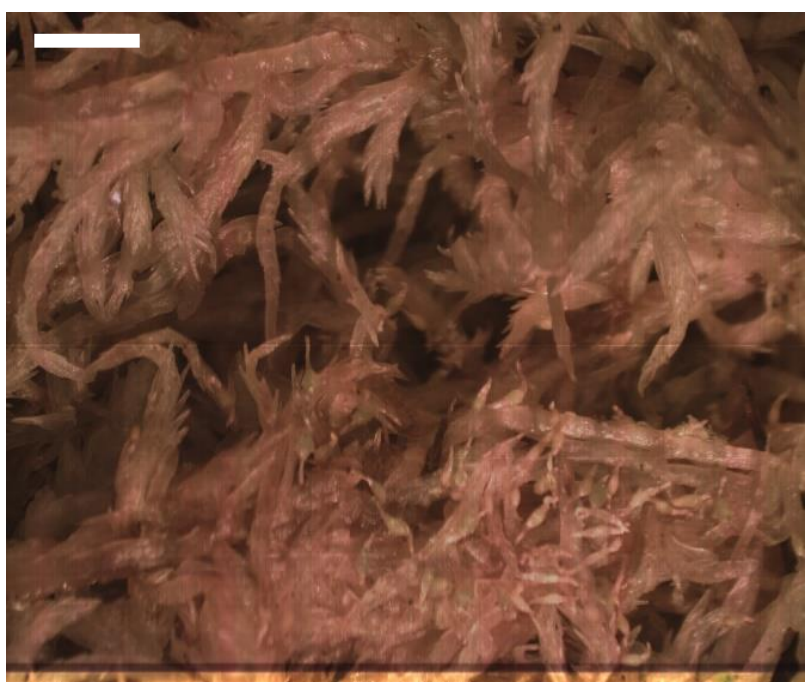

f

Figure 5. Asymbiotic seed germination, protocorm and seedling development of Bletilla striata in different media after 2 weeks period. (a) $1 / 2$ strength Phytamax P6668, (b) $1 / 2$ strength P6668 + coconut water, (c) P723, (d) P723 + coconut water, (e) $1 / 2$ strength MS, (f) Sphagnum Moss. Scale bars $=10 \mathrm{~mm}$. 


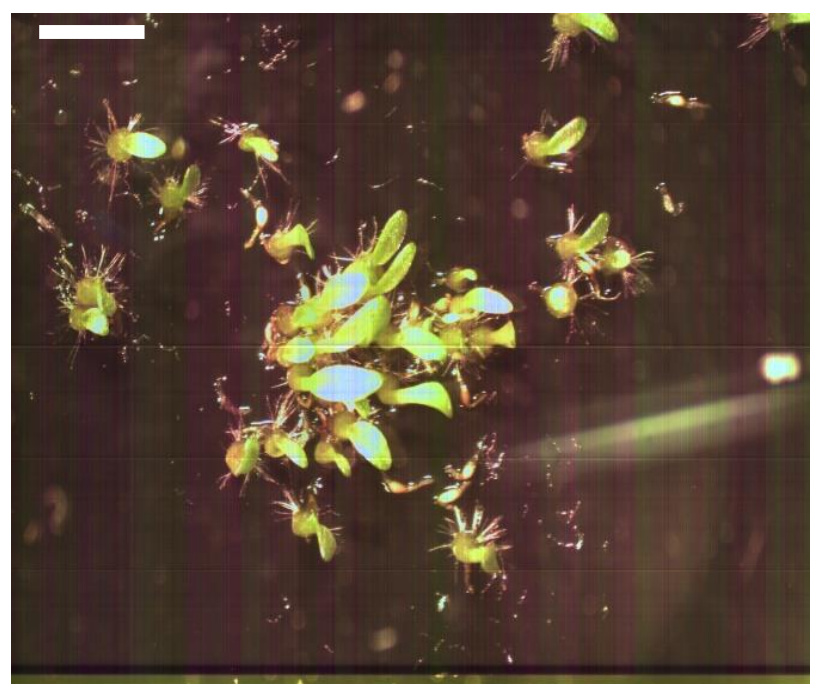

a

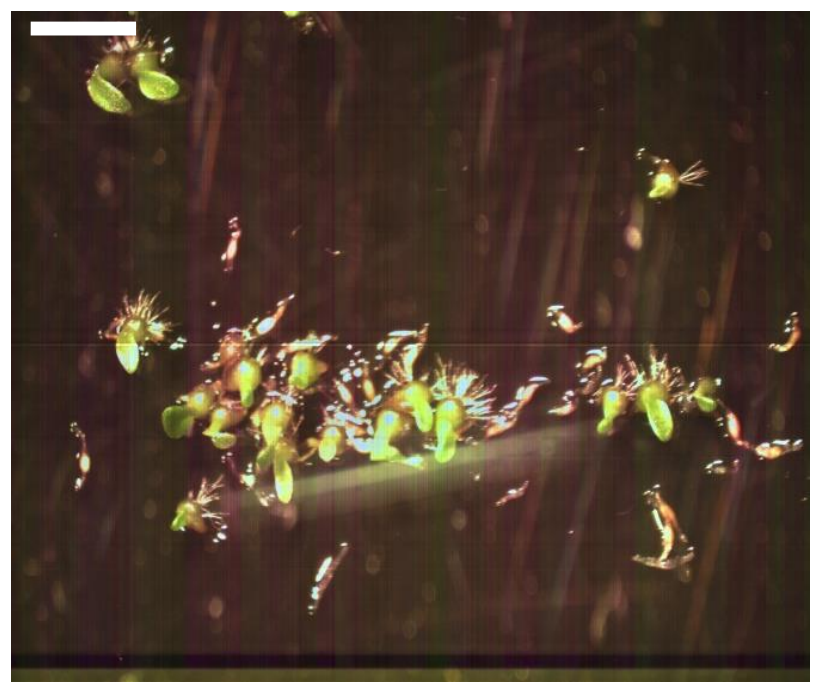

C

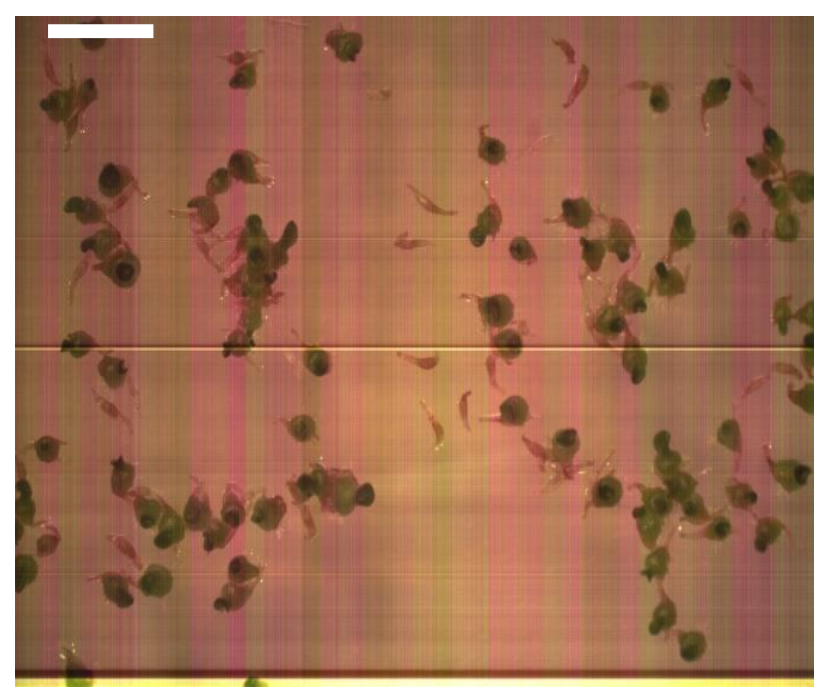

e

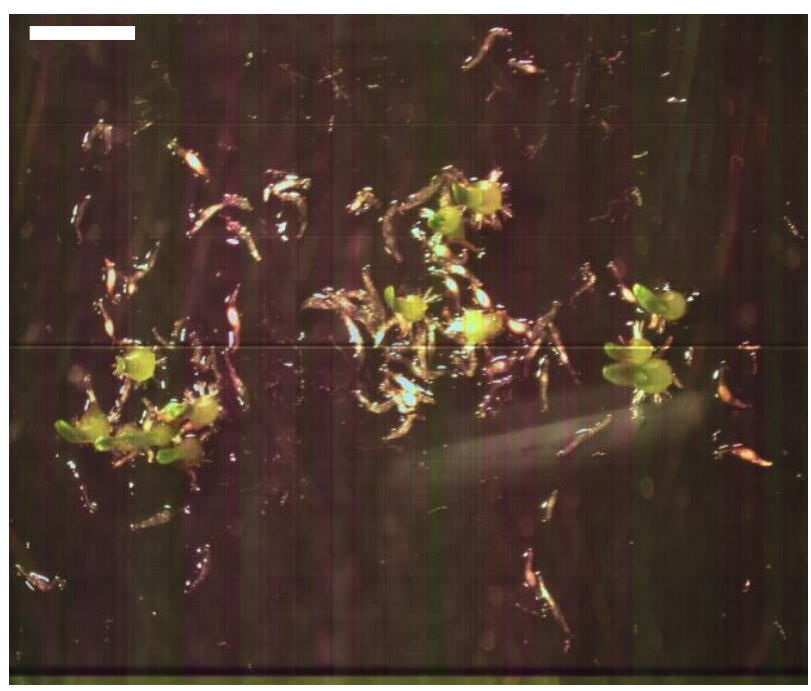

b

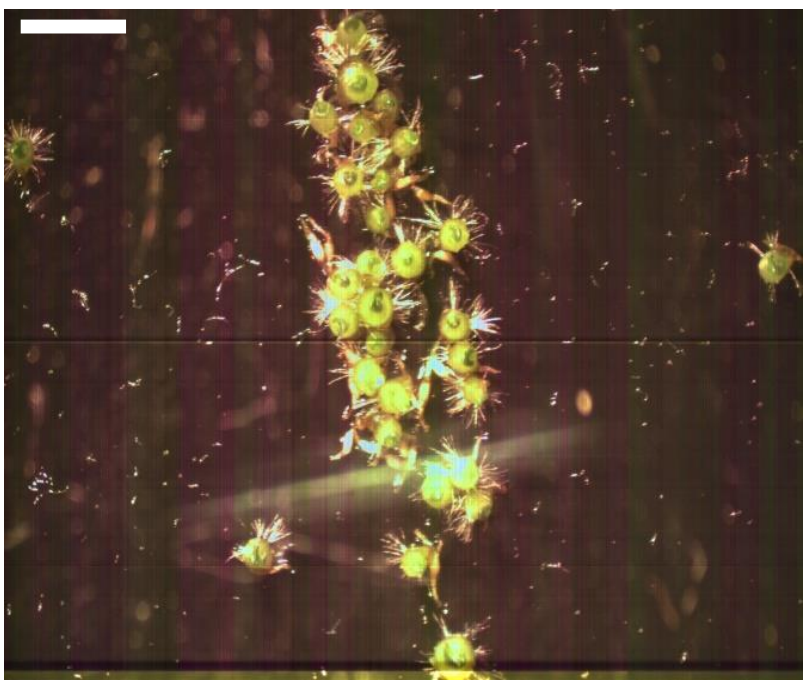

d

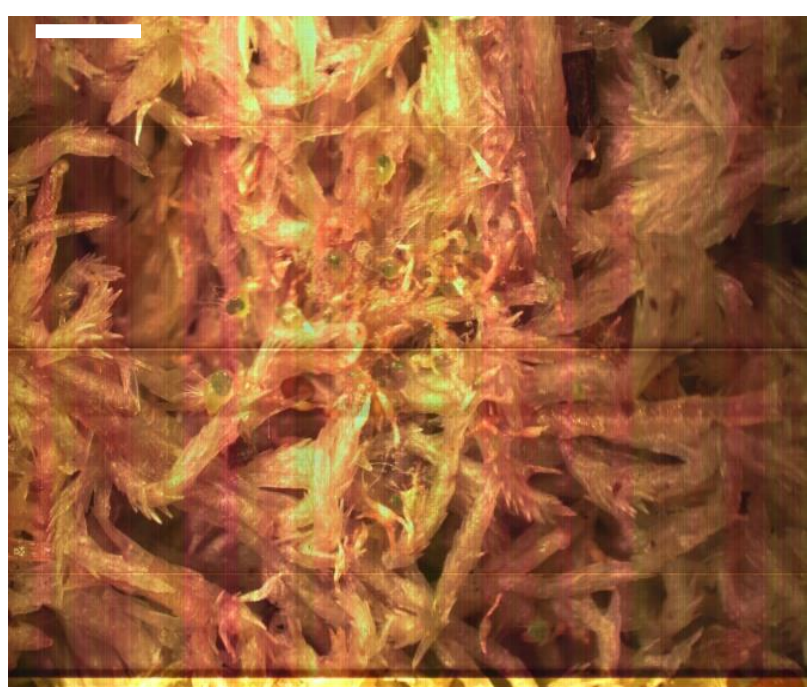

$\mathrm{f}$

Figure 6. Asymbiotic seed germination, protocorm and seedling development of Bletilla striata in different media after 3 weeks period. (a) $1 / 2$ strength Phytamax P6668, (b) $1 / 2$ strength P6668 + coconut water, (c) P723, (d) P723 + coconut water, (e) $1 / 2$ strength MS, (f) Sphagnum Moss. Scale bars $=10 \mathrm{~mm}$. 


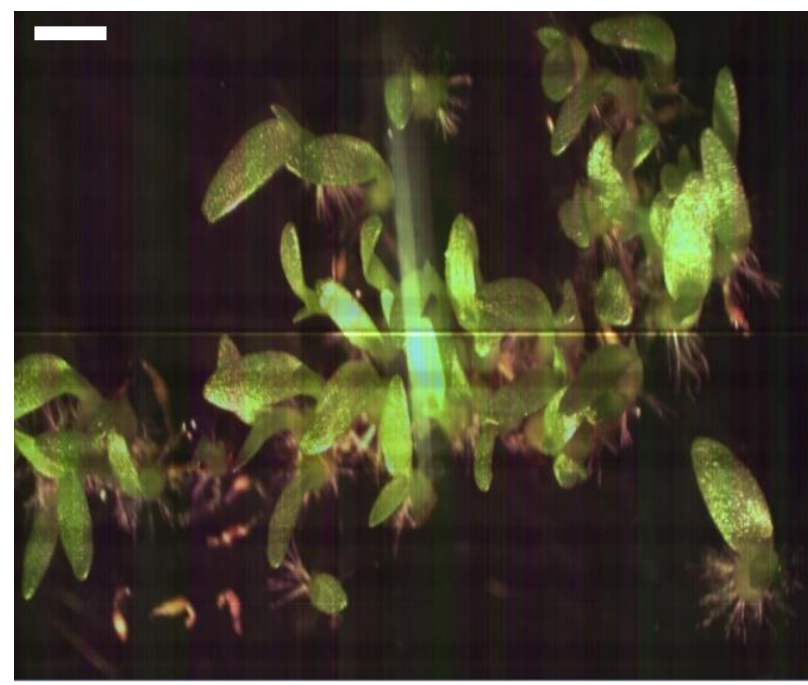

a

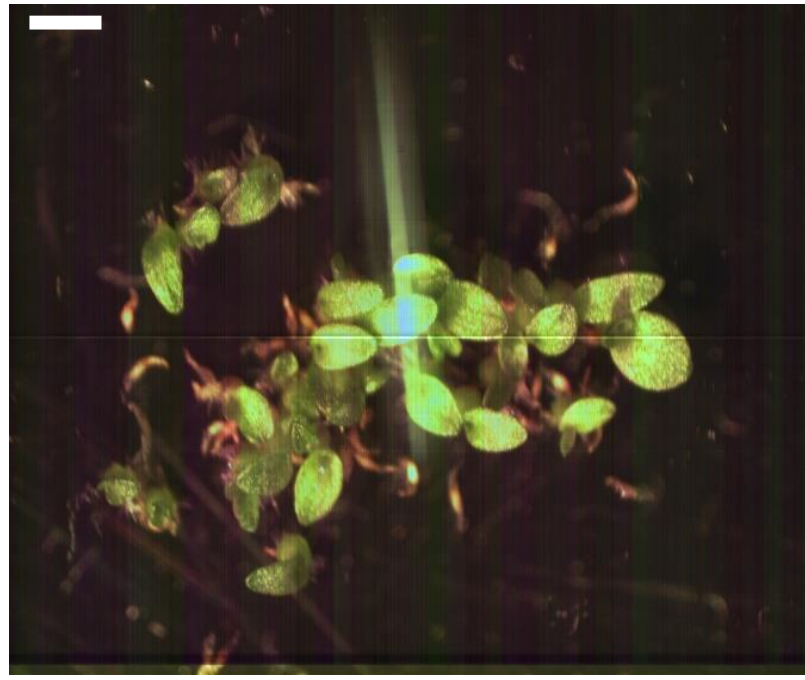

C

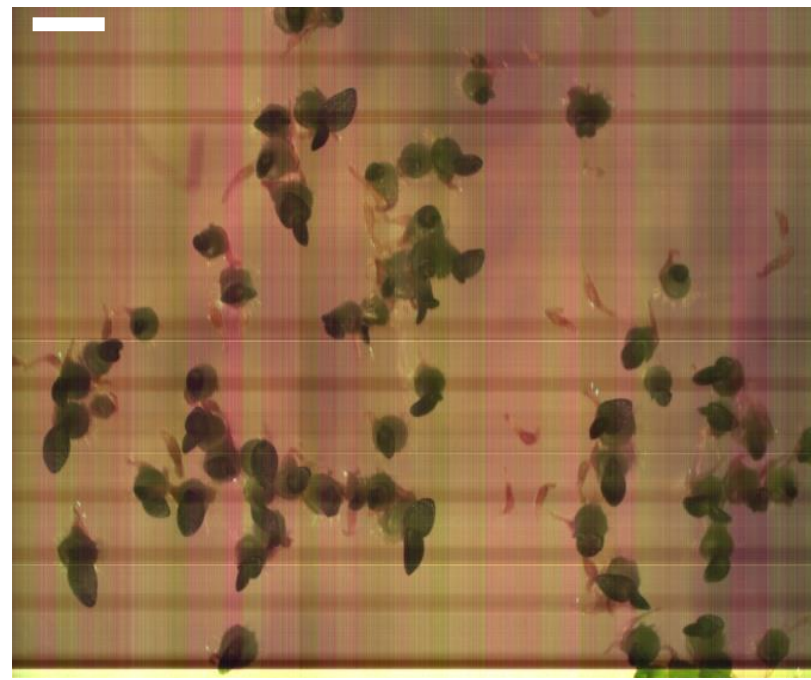

e

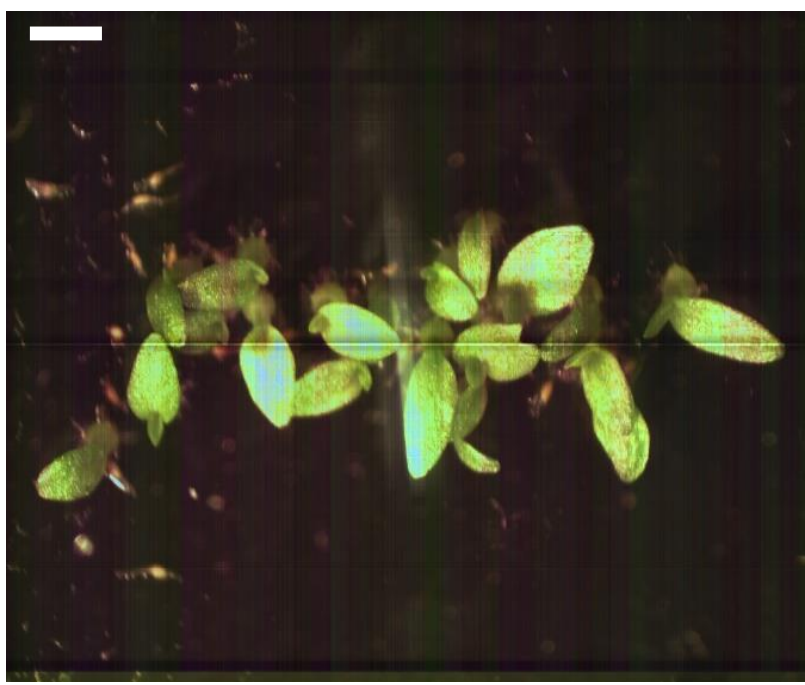

b

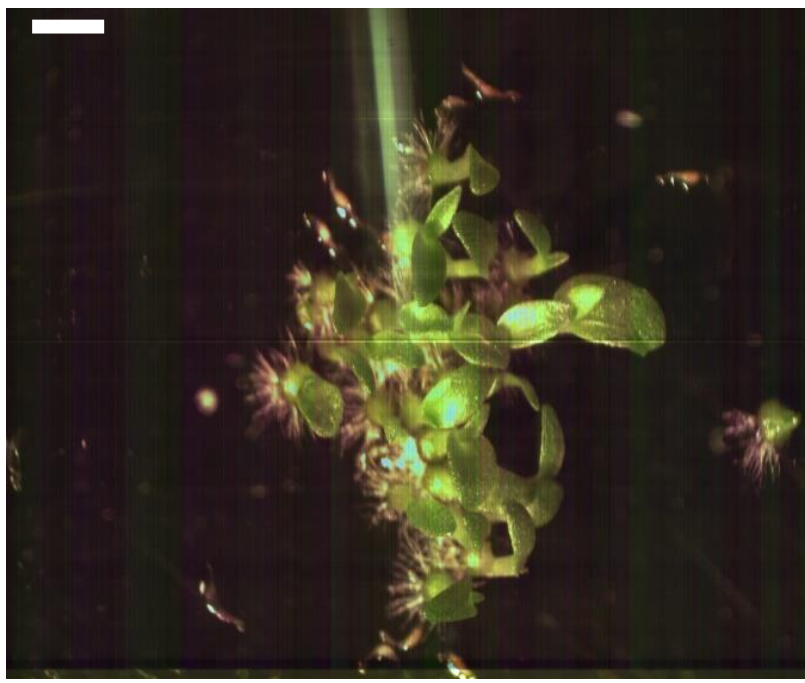

d

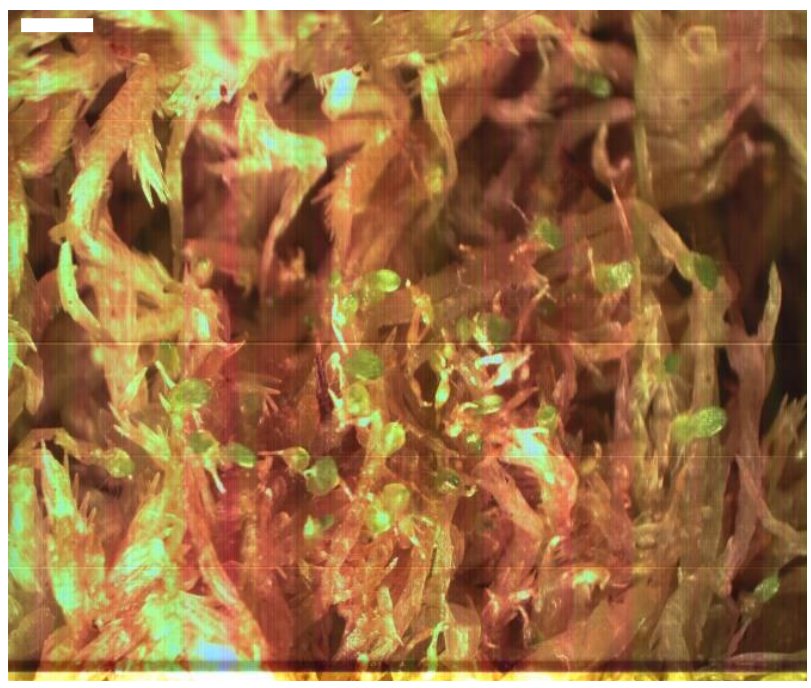

$f$

Figure 7. Asymbiotic seed germination, protocorm and seedling development of Bletilla striata in different media after 5 weeks period. (a) $1 / 2$ strength Phytamax P6668, (b) 1 1/2 strength P6668 + coconut water, (c) P723, (d) P723 + coconut water, (e) $1 / 2$ strength MS, (f) Sphagnum Moss. Scale bars $=10 \mathrm{~mm}$. 


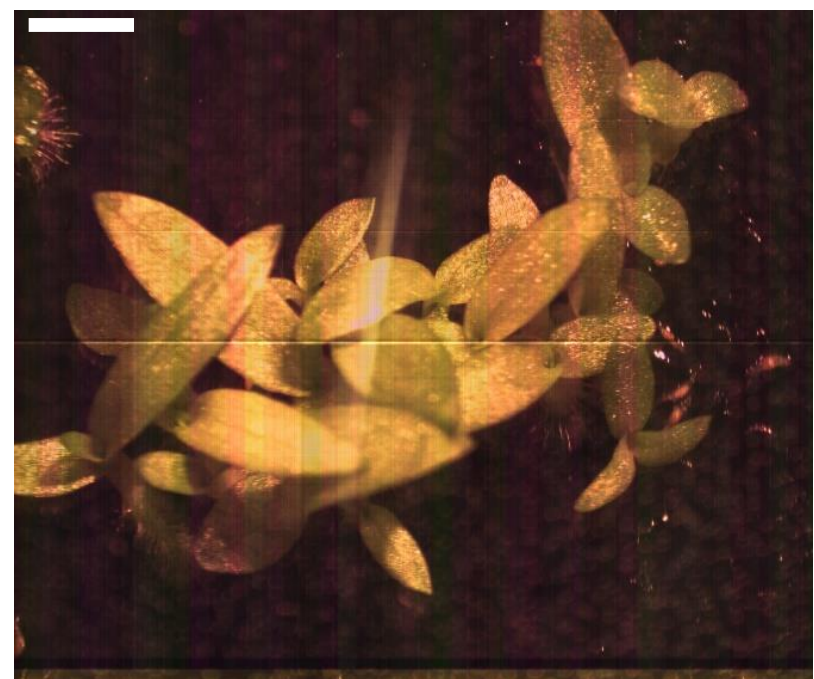

a

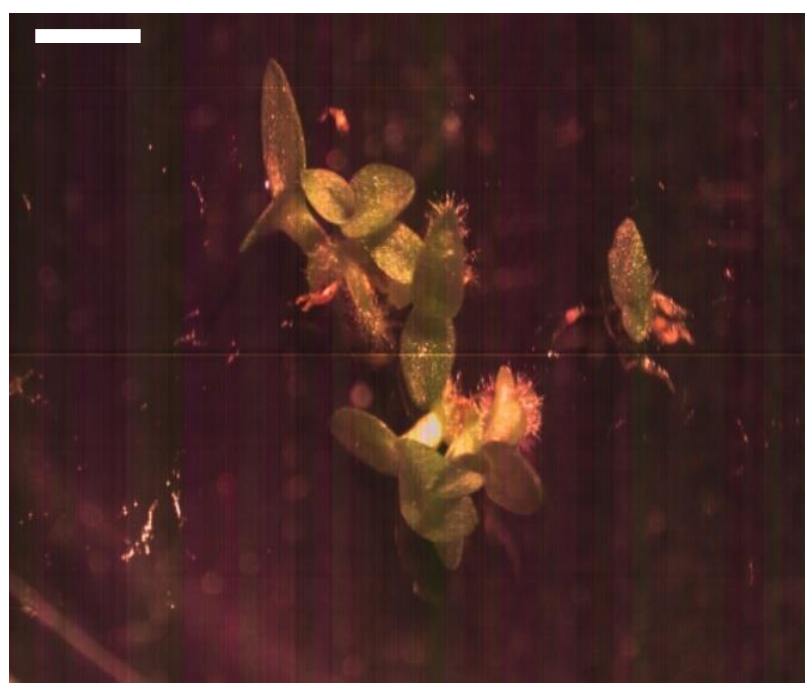

C

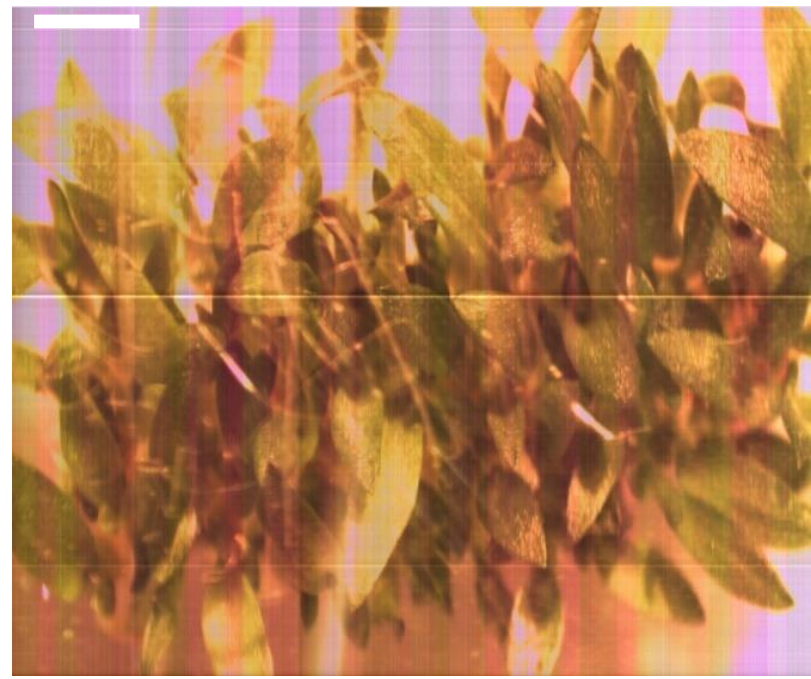

e

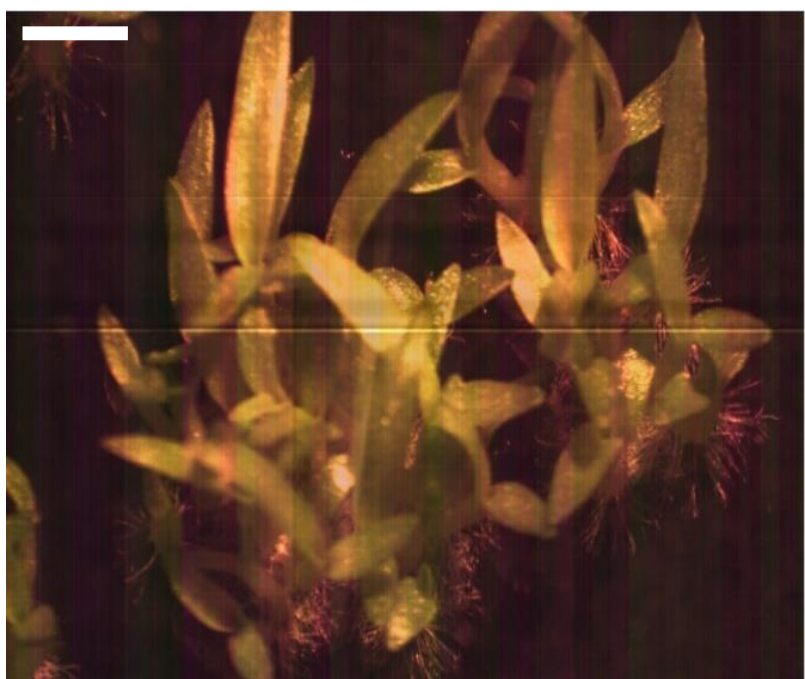

b

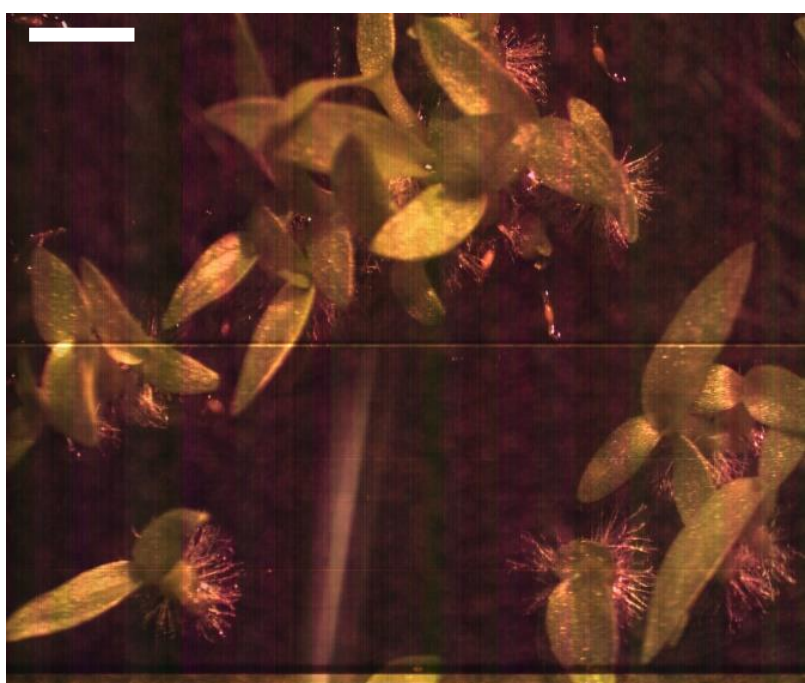

d

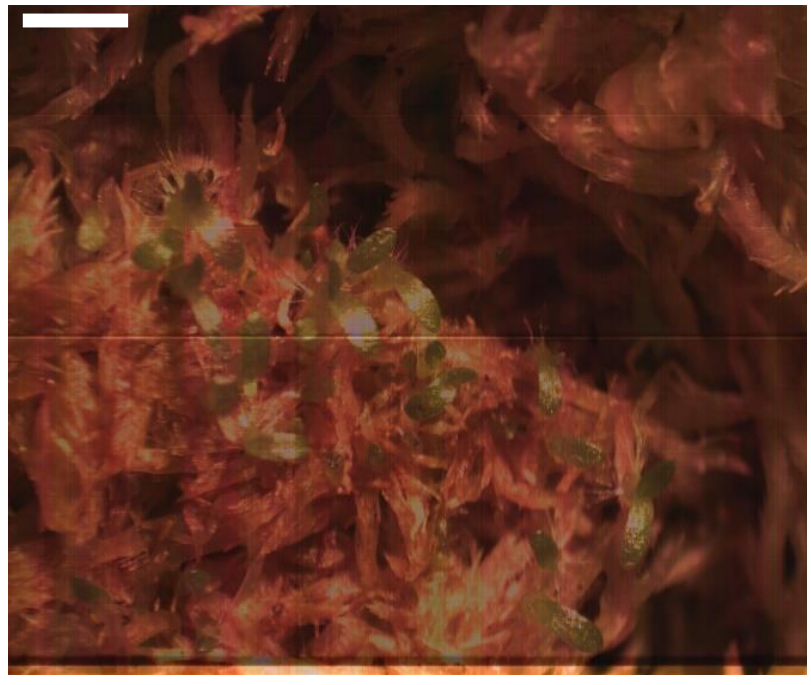

$f$

Figure 8. Asymbiotic seed germination, protocorm and seedling development of Bletilla striata in different media after 8 weeks period. (a) $1 / 2$ strength Phytamax P6668, (b) $1 / 2$ strength P6668 + coconut water, (c) P723, (d) P723 + coconut water, (e) $1 / 2$ strength MS, (f) Sphagnum Moss. Scale bars $=10 \mathrm{~mm}$. 


\section{Conclusion}

The results show that the seeds of Bletilla striata can be germinated and seedlings can be developed successfully under in vitro and ex vitro conditions. According to the present study, there were statistically significant differences between nutrition media in terms of germination and seedling development parameters. Different components like macro elements, micro elements, vitamins, and organics showed significant differences for asymbiotic in vitro germination. Different combinations of plant growth regulators with commercial orchid media can be investigated for further researches. Furthermore, different nutrition sprays can be applied to the sphagnum moss after the germination process in the future studies.

\section{Acknowledgements}

The authors thank Jean Watson and Mandy Smith at Writtle University College for help in the preparing media for the orchid seeds. We also would like to thank Charles Valin from Thompson \& Morgan Company (UK) for supplying orchid seeds.

\section{References}

Acemi, A., \& Özen, F. (2019). Optimization of in vitro asymbiotic seed germination protocol for Serapias vomeracea. The EuroBiotech Journal, 3:143-151.

Arditti, J., \& Ernst, R. (1984). Physiology of germinating orchid seeds, Cornell University Press.

Arditti, J. (1990) Orchid biology: Reviews and perspectives. Timber Press.

Arditti, J. (1992). Fundamentals of orchid biology. John Wiley \& Sons Publishing.

Arditti, J., \& Ernst, R. (1993). Micropropagation of Orchids. John Wiley \& Sons Publishing.

Arditti J., \& Ghani, A. (2000). Numerical and physical properties of orchid seeds and their biological implications. New Phytologist, 145:367-461.

Arditti, J. (2008). Micropropagation of Orchids $\left(2^{\text {nd }}\right.$ edition). Blackwell Publishing.

Bae, K.H., \& Choi, Y.E. (2008). In vitro germination of mature seed of Cypripedium guttatum. Division of Forestry and Natural Resources, p:282-283.

Bae, K.H., \& Kim, S.Y. (2015). Asymbiotic germination and seedling growth of Calanthe striata f. sieboldii Decne. ex Regel. Journal of Plant Biotechnology, 42:239-244.

Barrientos, B.A.B., \& Fang, J.Y. (2019). Influence of photoperiod and culture medium on the speed of asymbiotic seed germination and seedling development in Spathoglottis plicata. HortScience, 54:1570-1575.

Bektaş, E., \& Sökmen, A. (2016). In vitro seed germination, plantlet growth, tuberization, and synthetic seed production of Serapias vomeracea (Burm.f.) Briq. Turkish Journal of Botany, 40:584-894.

Bhadra, S.K., \& Hossain, M.M. (2003). In vitro germination and micropropagation of Geodorum densiflorum (Lam.) Schltr., an endangered orchid species. Plant Tissue Culture, 13:165-171.

Billard, C.E., Dalzotto, C.A., \& Lallana, V.H. (2013). Germination of Bletilla striata (Thunb.) Rchb. $f$. in liquid medium and plant evolution in semi-solid medium. Investigación Agraria Journal, 15:7-14.

Butcher, D., \& Marlow, S.A. (2008). Asymbiotic germination of epiphytic and terrestrial orchids. In Pritchard, H. (Ed.) Modern Methods in Orchid Conservation, the Role of Physiology, Ecology and Management (pp. 31-38). Cambridge University Press.

Calevo, J., Giovannini, A., Cornara, L., \& Peccenini, S. (2017). Asymbiotic seed germination of handpollinated terrestrial orchids. Acta Horticulturae, 1155:415-418.

Chou, L.C., \& Chang, D.C.N. (2004). Asymbiotic and symbiotic seed germination of Anoectochilus formosanus and Haemaria discolor and their F1 hybrids. Botanical Bulletin of Academia Sinica, 45:143-147.

Chu, C.C., \& Mudge, K.W. (1996). Propagation and Conservation of Native Lady's Slipper Orchids (Cypripedium acaule, C. calceolus, and C. reginae) [Conference Session], North American Native Terrestrial Orchids Propagation and Production Conference Proceedings, USA.

De Pauw, M.A., Remphrey, W.R., \& Palmer, C.E. (1995). The cytokinin preference for in vitro germination and protocorm growth of Cypripedium candidum. Annals of Botany, 75:267-275.

Ding, Y.D., \& Zheng, Z.F. (2016). Sterile seeds germination medium optimization. Journal of Yichun University, 38:74-76.

Dong, J.W., Xiong, L.C.J., Chen, X.H., Wang, W.Y., BeiLei, N.S., \& Ding, L.Z.T. (2014). Improving the antioxidant and antibacterial activities of fermented Bletilla striata with Fusarium avenaceum and Fusarium oxysporum. Process Biochemistry, 50:8-13.

Dressler, R.L. (1993). Phylogeny and Classification of the Orchid Family. Cambridge University Press.

Dulić, J., Ljubojević, M., Ognjanov, V., Barac, G., \& Dulic, T. (2019). In vitro germination and seedling development of two European orchid species, Himantoglossum jankae Somlyay, Kreutz \& Óvári and Spiranthes spiralis (L.) Chevall. In Vitro Cellular \& Developmental Biology, 55:380-391.

Dutra, D., Johnson, T.R., Kauth, P.J., Stewart S.L., Kane, M.E., \& Richardson, L. (2008). Asymbiotic seed germination, in vitro seedling development and greenhouse acclimatization of the threatened terrestrial orchid Bletia purpurea. Plant Cell, Tissue and Organ Culture, 94:11-21.

Fu, Z., Zhang, J., Li, H., Yang, B. (2006). Study on seed germination and rapid propagation of Bletilla striata Rchb.f. Wuhan Botanical Research, 24:80-82.

Godo, T., Fujiwara, K., Guan, K., \& Miyoshi, K. (2011). Effects of wavelength of LED-light on in vitro asymbiotic germination and seedling growth of Bletilla ochracea Schltr. (Orchidaceae). Plant Biotechnology, 28:397-400

Godo, T., Hashimoto, T., \& Nakata, M. (2020). The effects of illumination, temperature and 6-benzylaminoprine on asymbiotic seed germination and protocorm development in vitro in the achlorophyllous orchid Gastrodia pubilabiata Sawa. In Vitro Cellular \& Developmental Biology, 56:230-235.

Govaerts, R., Bernet, P., Kratochvil, K., Gerlach, G., Carr G., Alrich, P., Pridgeon, A.M., Pfahl, J., Campacci, M.A., Holland Baptista, D., Tigges, H., Shaw, J., Cribb, P., George, A., Kreuz, K., \& Wood, J. (2018). 
World Checklist of Orchidaceae. http://wcsp.science.kew.org/.

Gümüş, C. (2009). Investigations for the reproduction methods of some of the orchid species (Orchidaceae) used for obtaining salep in Western Black Sea region. PhD Thesis, Ankara University, Ankara.

Gümüş, C., \& Ellialtioglu, S. (2012). Seed germination and development of Serapias vomeracea (Burm.fil.) Briq. ssp. orientalis Greuter in tissue culture. Research Journal of Biotechnology, 7:4-8.

Gümüş, C., Ellialtıoğlu, Ş.Ş., \& Eman, Ş.B. (2017). Studies for obtaining the protocorms and plantlets in Orchis pinetorum, Anacamptis pyramidalis, and Dactylorhiza nieschalkiorum under in vitro conditions. International Journal of Forestry and Horticulture, 3:28-36.

Harrap, A.S. (2009). Orchids of Britain and Ireland (2 ${ }^{\text {nd }}$ Edition). A\&C Black Press

Hemrová, L., Kotilínek, M., Konečná, M., Paulic, R., Jersakova, J., Tesitelova, T., Knappova, J., \& Munzbergova, Z. (2019). Identification of drivers of landscape distribution of forest orchids using germination experiment and species distribution models. Oecologia, 190:411-423.

Huh, Y.S., Lee, J. K., Nam, S.Y., Paek K. Y., \& Suh G.U (2016). Improvement of asymbiotic seed germination and seedling development of Cypripedium macranthos Sw. with organic additives. Journal of Plant Biotechnology, 43:138-145.

Huh, Y.S., Lee, J.K., Paek, K.Y., Park, S.Y., Son, S.W., \& Suh, G.U. (2019). Effect of seed maturity on germination and proliferation of Cypripedium macranthos Sw. during asymbiotic seed culture. Acta Horticulturae, 1262:53-62.

Kauth, P. (2005). In Vitro Seed Germination and Seedling Development of Calopogon tuberosus and Sacoila lanceolata var. lanceolata: Two Florida Native Terrestrial Orchids. Master's Thesis, University of Florida, USA

Kim, D.H., Kang, K.W., Enkhtaivan, G., Jan, U., \& Sivanesan, I. (2019). Impact of activated charcoal, culture medium strength and thidiazuron on nonsymbiotic in vitro seed germination of Pecteilis radiate (Thunb.) Raf. South African Journal of Botany, 124:144-150.

Kindlmann, P., \& Zuzana, B. (1999). Flowering regimes of terrestrial orchids: unpredictability or regularity? Journal of Vegetation Science, 10:269-273.

Klavina, D., Druva-Lusite, I., \& Gailite, A. (2009). Asymbiotic cultivation in vitro of the endangered orchid Cypripedium calceolus L. and some aspects of ex vitro growth. Acta Horticulturae, 812:539-54.

Kulpa, D., \& Katron, J. (2012). Seed germination and plant development of Bletilla striata in vitro. Folia Pomeranae Universitatis Technologiae Stetinensis. Agricultura, Alimentaria, Piscaria et Zootechnica, 293:51-60.

Laurent, J. (2014). A Comparison of the germination stages of two species of Dactylorhiza orchid on three different asymbiotic growing media. Unpublished BSc dissertation, Writtle University College, UK.

Lee, Y.I. (2007). The asymbiotic seed germination of six Paphiopedilum species in relation to the time of seed collection and seed pretreatment. Acta Horticulturae, 755:381-386.

Liu, M., Shu, Y., Zhang, Y., Guo, C., Xu, G., \& Gao, J. (2017). Seed germination and effective protocorm proliferation system establishment for Bletilla striata (Thumb.) Reichb. f. Journal of Southern Agriculture, 48:2223-2227.

Magrini, S., De Vitis, M., Torelli, D., Santi, L., \& Zucconi, L. (2019). Seed banking of terrestrial orchids: evaluation of seed quality in Anacamptis following 4year dry storage. Plant Biology Journal, 21:544-550.

McKendrick, S. (2000). In vitro germination of orchids: a manual. https://docplayer.net/29831334-In-vitrogermination-of-orchids-a-manual.html. Accessed: 14 May 2020.

Min, L., Shu, Y.T., Zhang, Y.Q., Guo, C., Xu, G.L., \& Gao, J.S. (2017). Seed germination and effective protocorm proliferation system establishment for Bletilla striata (Thumb.) Reichb. f. Journal of Southern Agriculture, 48:2223-2227.

Murashige, T., \& Skoog, F. (1962). A revised medium for rapid growth and bioassays with tobacco tissue cultures. Physiologia Plantarum, 15:473-497.

Nie, N., Zhu, Y., Tian, M., Hua, J.W., Wang, L., \& Qin, M.J. (2016). Morphological and cytohistological observations of seed germination and protocorm development of Bletilla striata. China Journal of Chinese Materia Medica, 41:1446-1449.

Paek, K.Y., \& Yeung, E.C., (1991). The effects of 1naphthaleneacetic acid and $\mathrm{N}$-benzyladenine on the growth of Cymbidium forrestii rhizomes in vitro. Plant Cell, Tissue and Organ Culture, 24:65-71.

Pan, M.J., \& van Staden, J. (1998). The use of charcoal in in vitro culture - a review. Plant Growth Regulation, 26:155-163.

Peng, Q., Lic, M., Xuea, F., \& Liu, H., (2014). Structure and immunobiological activity of a new polysaccharide from Bletilla striata. Carbohydrate Polymers, 107:119-123.

Pereira, G., Albornoz, V., Muñoz-Tapia, L., Romero, C., \& Atala, C. (2015). Asymbiotic germination of Bipinnula fimbriata (Orchidaceae) seeds in different culture media. Seed Science \& Technology. 43:367-377.

Pereira, G., Albornoz, V., Romero, C., Lara, S., SánchezOlate, M., Darcy, R., \& Atala, C. (2017). Asymbiotic germination in three Chloraea species (Orchidaceae) from Chile. Gayana Botánica, 74:131-139.

Pierik, R.L.M., Sprenkels, P.A., Van der Harst, B., \& Van der Meys, Q. (1988). Seed germination and further development of plantlets of Paphiopedilum ciliolare Pfitz. in vitro. Scientia Horticulturae, 34:139-153.

Quiroz, K., Saavedra, J., Vogel, H., Verdugo, G., Caligari, P.D.S., \& García-Gonzáles, R. (2017). In vitro asymbiotic germination for micropropagation of the recalcitrant terrestrial orchid Chloraea crispa (Orchidaceae). Applications in Plant Sciences. 5:1600142.

Rasmussen, H. (1995). Terrestrial Orchids from Seed to Mycotrophic Plant. Cambridge University Press.

Seaton, P., \& Ramsay, M. (2005). Growing Orchids from Seed. Royal Botanic Gardens Kew.

Seaton, P., Cribb, P., Ramsay, M., \& Haggar, J. (2011). Growing Hardy Orchids. Royal Botanic Gardens Kew.

Song, X., Chen, X., Shang, L., \& Yang, P. (2014). Study on efficient seed germination of Bletilla striata in vitro. Modern Chinese Medicine, (9):13.

Stenberg, M.L., \& Kane, M.E. (1998). In vitro seed germination and greenhouse cultivation of Encyclia boothiana var. erythronioides, and endangered Florida orchid. The Scientific Journal of the American Orchid Society, 13:101-112. 
Stewart, S.L., \& Kane, M.E. (2007). Symbiotic seed germination and evidence for in vitro mycobiont specificity in Spiranthes brevilabris (Orchidaceae) and its implications for species-level conservation. In Vitro Cellular \& Developmental Biology, 43:178-186.

Su-Qin, Y.U. (2010). The study on seed germination effect of Bletilla striata under the different culture condition. Journal of Anhui Agricultural Sciences, 38:8421-8422.

Szendrak, E. (1997). Asymbiotic in vitro seed germination, micropropagation and scanning electron microscopy of several temperate terrestrial orchids (Orchidaceae). PhD Thesis, University of Nebraska, USA.

Tan, K.W. (1969). The systematic status of the genus Bletilla (Orchidaceae). Brittonia, 21:202-214.

Thomas, T.D. (2008). The role activated charcoal in plant tissue culture. Biotechnology Advances, 26:618-631.

Thakur, U., \& Dongarwar, N. (2017). Asymbiotic seed germination, seedling development and tuberization of Peristylus lawii Wight (Orchidaceae), a rare terrestrial orchid. Hislopia Journal, 10:59-72.

Tullock, J. (2005). Growing Hardy Orchids. Timber Press. London.

Wang, Y., Liu, D., Chen, S., Wang, Y., Jiang, H., \& Yin, $H$. ., (2013). A new glucomannan from Bletilla striata: Structural and anti-fibrosis effects. Fitoterapia. 92:7278.

Wei, X. M., Liu, Y., Wang, X.Y., Gao, Z.T., Yao, S.M., \& Han, J.P. (2018). Progress on research of tissue culture of Bletilla striata. Chinese Herbal Medicines, 10:23-26.

Xiang, Y., Ye, Qing, Li, W., Xu, W., \& Yang, H., (2013). Preparation of wet-spun polysaccharide fibers from Chinese medicinal Bletilla striata. Materials Letters, 117:208-210.

Yan, N., Hu, H., Huang, J., Xu, K., Wang, H., \& Zhou, Z. (2006). Micropropagation of Cypripedium flavum through multiple shoots of seedlings derived from mature seeds. Plant Cell, Tissue and Organ Culture, 84:113-117.

Ye, J., Zheng, X.J., Guan, C.D., Niu, Y., \& Ma, H.Y (2010). Seed germination and tissue culture of Bletilla striata. Journal of Yunnan University, 32:422-425.

YiLi, L., WeiPing, L., DanDan, M., LiangYan, H., FuSheng, J., JianGuo, Y., \& ZhiShan, D. (2012). Study on tissue culture and rapid breeding of Bletilla striata. Chinese Archives of Traditional Chinese Medicine, 30:336-339.

Zeng, S., Wu, K., Silva, J.A.T.D. , Zhang, J., Chen, Z., Xia, N., \& Duan, J. (2012). Asymbiotic seed germination, seedling development and reintroduction of Paphiopedilum wardii Sumerh., an endangered terrestrial orchid. Scientia Horticulturae, 138:198-209.

Zhang, Y., Li, B., \& Li, S.F. (2009). Seed germination and seedling morphogenesis of Bletilla striata under the different culture medium. Acta Botanica BorealiOccidentalia Sinica, 29:1584-1589.

Zhang, Y., Lee Y., Deng L., \& Zhao S. (2013). Asymbiotic germination of immature seeds and the seedling development of Cypripedium macranthos Sw., an endangered lady's slipper orchid. Scientia Horticulturae, 164:130-136.

Zhang, Y., Li, B., Li, R.J., \& Li, S.F. (2013). Study on observation of aseptic germination of Bletilla striata seeds and rapid propagation of Bletilla bulbocodioides. Northern Horticulture, 3:158-160.

Zhang, M., Shao, Q., Xu, E., Wang, Z., Wang, Z., \& Yin, L. (2019). Bletilla striata: a review of seedling propagation and cultivation modes. Physiology and Molecular Biology of Plants, 25:601-609.

Zhi-Hui F., Jian-Xia Z., Un, L.H., \& Bo, Y. (2006). Study on seed germination and rapid propagation of Bletilla striata 'Rchb f.' Journal of Wuhan Botanical Research. 24:80-82. 